\title{
Jogpolitika
}

\author{
JÓZSA ZOLTÁN*
}

\section{A jóléti szolgáltatások decentralizációja Franciaországban}

\author{
decentralizáció - megye (département) - jövedelemminimum-támogatás - \\ jóléti szolgáltatások reformja - intézményi szerkezet - hatékonyság
}

A nyolcvanas-kilencvenes években, a nyugat-európai országokban az intézményi reformok egyik meghatározó iránya az állami funkciók decentralizálása ${ }^{1}$ volt. A közfeladatok megosztásának egyre szélesedő gyakorlata azt ígérte, hogy ha az állam közelebb kerül a polgárokhoz, akkor növekszik a közszolgáltatások hatékonysága, javulhat az elszámoltathatóság és erősödhet a részvétel is.

Ugyanakkor viszonylag kevés megbízható adat áll rendelkezésre arra vonatkozóan, hogy milyen következményekkel járt egyes feladatok decentralizálása. Nyitott kérdés, hogy a reformok szándékolt következményei mellett jelentkeztek-e nem kívánatos mellékhatások? Mivel magyarázható ezek kialakulása?

Hasonló bizonytalanság érzékelhető abban a tekintetben is, hogy a decentralizációs reform a jó kormányzás ${ }^{2}$ elengedhetetlen feltétele, vagy csupán arról a tendenciáról ${ }^{3}$ van szó, melynek nyomán a központi szervek feladatokat adnak át a szubnacionális

* Dr. Józsa Zoltán egyetemi docens, Szegedi Egyetem Állam- és Jogtudományi Kar Közigazgatási Jogi Tanszék, jozo@juris.u-szeged.hu.

1 The World Bank: Decentralization and Local Democracy in the World: First Global Report by United Cities and Local Governments 2008, http://documents.worldbank.org/curated/en/728181468331905029/ Decentralization-and-local-democracy-in-the-world-2008-first-global-report-by-united-cities-and-localgovernments (2017. 07. 10.).

2 A jó kormányzás számtalan definíciója ismeretes. A fogalom értelmezését illetően kibontakozó vitáról lásd például: GAJduschek György: A közigazgatás szervezeti jellemzői - összehasonlító aspektusból. In: Szamel Katalin-Balázs István-Gajduschek György-Koi Gyula (szerk.): Az Európai Unió tagállamainak közigazgatása. CompLex Kiadó, Budapest, 2011, 54-57.

3 Az európai országok gyakorlatának áttekintését adja például DE VRIES, Michiel S.: The Rise and Fall of Decentralization: A Comparative Analyses of Arguments and Practices in European Countries. European Journal of Political Research, 2000/2, 204-224. 
szinteknek, azon felismerés alapján, hogy a helyi igények és szükségletek alapján hozott lokális döntések közvetetten a politikai stabilitást ${ }^{4}$ és a nemzeti egységet is elösegíthetik.

A nemzetközi tapasztalatok azt mutatják, hogy különösen kedvezőtlen gazdasági, pénzügyi, költségvetési mutatók esetén gyakori a központi feladatok átadása, gyakran a szubszidiaritás jelszava alatt, melynek következtében eszköz- és forrásigényes közszolgáltatások kerülnek a helyi szervezetek hatáskörébe. Ily módon az állam a felelősségét és a megvalósítással járó nehézségeket is átháríthatja (blame shifting), szabadulván ezzel a bűnbak szerepéből.

Kevésbé ismert, hogy a delegált feladatok végrehajtása versengő célokat ${ }^{5}$ eredményezhet, valamint az eredeti funkciók megvalósításának színvonalát is leronthatja, ${ }^{6}$ mivel kevesebb a lehetőség a helyi önállóság által biztosított mozgástér, mérlegelés gyakorlására. Emellett az alacsonyabb szintű szakismeret és a specializáció hiánya szintén csökkentheti a hatékonyságot. ${ }^{7}$

Megalapozottak azok a kritikák is, melyek szerint a decentralizációs lépések kiugró teljesítménykülönbségekhez vezethetnek, mivel felerősíthetik a már létező területi, társadalmi, szociális, kulturális stb. egyenlőtlenségeket. Mindez negatívan hathat az azonos életkörülményekkel és közszolgáltatásokkal kapcsolatos - jogos elvárásokra. Nem meglepő tehát, hogy föként a 2008-2009-es gazdasági, pénzügyi válságot követően, a kedvezőtlen hatások ellensúlyozására jó néhány ország ${ }^{8}$ új stratégiai irányt tüzött maga elé: a recentralizációt, a közszolgáltatások kisebb-nagyobb részének állami kézbe vételét.

Az európai országok közigazgatási reformjainak elemzése alapján arra a következtetésre lehet jutni, hogy a reformok - így a decentralizációt célul kitüző közpolitikai programok - sikerességét és teljesítménydifferenciáit nem elsősorban a feladatok szintek közötti elosztása határozza meg, hanem a reform megvalósítása, az aktuális, politikai, gazdasági, társadalmi szituáció, mely a reform intézményi kereteként $^{9}$ szolgál. Ezt a megállapítást igazolja a francia jóléti szolgáltatások decentralizálásának sikertelen kísérlete is.

4 Az igazgatási reformoknak csak ritkán célja a decentralizáció, alkalmazásának valódi oka legtöbb esetben a hatalommegosztás iránti igény kielégítése, https://books.google.hu/books?hl=hu\&lr=\&id=cj4XHqbpjQoC \&oi=fnd\&pg=PR5\&dq=dillinger+william\&ots=iz_vK4eGr6\&sig=Epn34kMTz2e2NUQKXYcToLUmKI8\&red ir_esc=y\#v=onepage\&q=dillinger\%20william\&f=false (2017. 07. 16.).

5 A közszervezeteknek, szemben a magánszervezetekkel a jogszerüség, az egyenlő elbánás, a méltányosság stb. követelményei mellett a hatékonyság és a gazdaságosság követelményének is meg kell felelnie. A helyi önkormányzatok többfunkciós szervezetek, változó célokkal és értékekkel. Ezeket csak a politikai folyamat értékei alapján lehet összeegyeztetni, amellett, hogy a szervezeti teljesítmény és siker mérése is - lényegében - vitatott eljárás.

6 Különösen akkor, ha az átadott feladatoknak nincs biztosítva a költségvetési fedezete.

7 A hatékonysághoz hasonlóan a koordináció és a demokratikus ellenőrzés vonatkozásában is meglehetősen ellentmondásos feltételezések ismeretesek a decentralizáció hatásával összefüggésben. Lásd erre vonatkozóan PÁlnÉ KovÁcs Ilona: Dilemmák a jó kormányzás és a decentralizáció összefüggéseiről. Új Magyar Közigazgatás, 2013/12, 1-7.

8 Példaként megemlíthető Hollandia vagy akár Magyarország.

9 KunLmAnn, Sabine-WAYEnBERG, Ellen: Institutional Impact Assessement in Multi-Level Systems: Conceptualizing Decentralization Effects from a Comparative Perspective. International Review of Administrative Sciences, 2016/2, 233-254. 
A tanulmány első része a decentralizáció elvének lehetséges értelmezését, az alkalmazás előnyeit és hátrányait, valamint a szervezeti teljesítménnyel való kapcsolatát vázolja fel. Ezt követően az önkormányzati rendszerek tipológiája a szubnacionális szintek strukturális és funkcionális jellemzőit mutatja be, melyek hatnak a közpolitikai döntések végrehajtására. Végül a francia jóléti és szociális ellátórendszer reformjának elemzése megerősíti azt a feltételezést, hogy a történeti, társadalmi, intézményi, kulturális sajátosságok még a kis léptékű (inkrementális) változások megvalósítása során sem hagyhatók figyelmen kívül.

\section{A decentralizáció elméleti összefüggései}

A decentralizáció iránti érdeklődés nem mai keletű. Már jóval a nyolcvanas éveket megelőzően a koloniális uralom meghosszabbításának egyik eszközeként is alkalmazták az afrikai országokban. A fejlődő országok a stagnáló gazdaság, míg a multilaterális intézmények az alacsony hatékonyságú központi bürokráciák orvoslásának módszereként tekintettek erre a lehetőségre. Régóta egyértelmű az is, hogy a helyi politikusok, valamint a civil társadalom nyomása a központi hatalom megosztása iránt elismerést nyerhet a decentralizáció révén, mivel ez a hatalom demokratizálódását jelenti.

Az elmúlt évtizedekben a fogalom széles körü elterjedése és használata nagy fokú bizonytalanságot eredményezett a decentralizáció jelentését illetően. A nyelvi differenciák $s$ az eltérő tudományos megközelítések a koncepció változatos alkalmazásához vezettek. Jóllehet önmagában a többes jelentés nem jelent problémát, azonban mind a túl tág értelmezés, mind pedig az indokolatlanul korlátozott jelentéstartalom kerülendő.

Különösen félrevezető, ha a koncepciót normatív értékekkel társítják, ahogy rendszerint a decentralizációt is pozitív értéktartalommal kötik össze. Ilyen többek között a decentralizáció, a demokrácia, a részvétel vagy a piaci reformok összekapcsolása. Természetesen ezekben az esetekben hipotézisekről van szó, melyek empirikus igazolása szükséges.

Mivel a decentralizáció relatív fogalom, gyakori helyette olyan terminusok használata, melyek nem hordoznak értéktartalmat, mint például a több szintü kormányzás, hálózatos kormányzás, szétszórt kormányzás stb. Mindez azonban az alapproblémát, a definíció kérdését nem oldja meg. Eltérő definíciók használata eltérő decentralizációs ismérvekhez vezethet, s éppígy gondot okozhat, ha az elemzés fókusza különböző szintekre koncentrál, akár a nemzetire, vagy akár a területire.

A fogalmi és az ok-okozati összefüggések alapján indokolt a decentralizáció több dimenzióját ${ }^{10}$ megkülönböztetni. Az egyik dimenzió interakcióba léphet ${ }^{11}$ vagy össze-

10 Schneider tanulmányában a decentralizáció három dimenzióját említi: a fiskális, az igazgatási és a politikai decentralizációt. SchneIDER, Aaron: Decentralization: Conceptualization and Measurement. Studies in Comparative International Development, 2003/3, 33-36.

11 A pénzügyi decentralizáció erősítheti a helyi szint adminisztratív önállóságát. Ugyanakkor a fiskális decentralizáció csökkentheti a helyi igazgatási autonómiát, ha a kormány az átadott források felhasználását bürokratikus szabályozással és ellenőrzéssel szisztematikusan ellehetetleníti. 
kapcsolódhat egy másikkal, így meghatározott okok és hatások láncolatához, míg a másik dimenzió különböző vagy ellentétes okok és hatások láncolatához vezethet.

A decentralizáció, dekoncentráció tipizálása meglehetősen nagy változatosságot mutat mind a hazai, ${ }^{12}$ mind pedig a nemzetközi ${ }^{13}$ szakirodalomban. Leggyakrabban négy alaptípus határolható el, azzal a megszorítással, hogy az egyes verziókon belül további altípusok is léteznek:

1. Politikai decentralizáció: az állami funkció teljes körüen a helyi szervek hatáskörébe kerül. A demokratikusan választott helyi testület felelőssége teljes a tervezés, finanszírozás és megvalósítás kérdéseiben.

2. Adminisztratív decentralizáció: a választott helyi testület nem rendelkezik döntési joggal az átadott funkciók felett, ugyanakkor a szervezete és a feladatok végrehajtása tekintetében önálló. Lényegében mint az állam ügynöke jár el, annak felügyelete és ellenőrzése mellett.

3. Vertikális dekoncentráció: a központi szervek feladatait az állam területi vagy helyi szerveinek delegálják, melyek a központi szervezetrendszer részét képezik, s azok funkcióját valósítják meg területi vagy helyi szinten.

4. Horizontális dekoncentráció: a helyi szervekre ruházott speciális feladat az önkormányzati portfólióból kikerülve elkülönült adminisztratív szerv hatáskörébe kerül (quangos), ${ }^{14}$ melynek finanszírozása és felügyelete a központi szervek révén történik.

1. táblázat. A decentralizáció előnyei és hátrányai

\begin{tabular}{|l|l|l|}
\hline \multicolumn{1}{|c|}{ Hatásindikátor } & \multicolumn{1}{|c|}{ Feltételezett pozitív hatás } & \multicolumn{1}{c|}{ Feltételezett negatív hatás } \\
\hline $\begin{array}{l}\text { Gazdaságosság: } \\
\text { eröforrás-takarékosság, } \\
\text { növekvö/csökkenő költségek, } \\
\text { méretgazdaságosság, } \\
\text { kombinált eljárások }\end{array}$ & $\begin{array}{l}\text { A kis egységek közötti } \\
\text { verseny emeli } \\
\text { a hatékonyságot }\end{array}$ & $\begin{array}{l}\text { A méretgazdaságosság } \\
\text { romlása, szervezeti duplikáció, } \\
\text { költségnövekedés a központi } \\
\text { szervek terhére }\end{array}$ \\
\hline $\begin{array}{l}\text { Hatékonyság: } \\
\text { jogegyenlöség, professzioná- } \\
\text { lis minőség, ügyfél/használó } \\
\text { orientáció, elérhetőség }\end{array}$ & $\begin{array}{l}\text { A választók közelsége és a } \\
\text { helyi ismeret növeli a szolgál- } \\
\text { tatási célok pontosságát és a } \\
\text { helyi preferenciák figyelembe- } \\
\text { vételének a lehetőségét. } \\
\text { Innovációs potenciál a rugal- } \\
\text { mas alkalmazkodás és a kí- } \\
\text { sérleti tapasztalatok miatt }\end{array}$ & $\begin{array}{l}\text { A munkamegosztás fejletlen- } \\
\text { seakmai kompetencia hiánya }\end{array}$ \\
$\begin{array}{l}\text { Gyenge szakmai függetlenség } \\
\text { a helyi politikusok befolyása } \\
\text { miatt }\end{array}$ \\
\hline $\begin{array}{l}\text { Horizontális koordináció: } \\
\text { szervezetközi koordináció, a } \\
\text { konfliktusok intenzitása megnórtelem és a } \\
\text { a koordinációs eljárásban, } \\
\text { hozzájárulás a problémák } \\
\text { meghatározásához }\end{array}$ & $\begin{array}{l}\text { Pozitív koordináció a decent- } \\
\text { ralizált többcélú joghatósá- } \\
\text { gokban }\end{array}$ & $\begin{array}{l}\text { Téves percepciók az egyéni } \\
\text { teljesítménycélokat illetően }\end{array}$ \\
\hline
\end{tabular}

12 PÁlnÉ KovÁcs Ilona: Helyi kormányzás Magyarországon. Dialóg Campus Kiadó, Budapest-Pécs. 2008.

13 Andrews, Cristina W. - De VRIES, Michiel S.: High Expectation, Varying Outcomes. Decentralization and Participation in Brazil, Japan, Russia and Sweden. International Review of Administrative Sciences, 2007/3, 424-451.

14 Quasi-autonomous non-governmental organizations, azaz kvázi független nem kormányzati szervek. 


\begin{tabular}{|l|l|l|}
\hline \multicolumn{1}{|c|}{ Hatásindikátor } & \multicolumn{1}{|c|}{ Feltételezett pozitív hatás } & \multicolumn{1}{c|}{ Feltételezett negatív hatás } \\
\hline $\begin{array}{l}\text { Vertikális koordináció: } \\
\text { szintek közötti koordináció, } \\
\text { konfliktusok a koordinációs } \\
\text { eljárásban, hozzájárulás } \\
\text { a problémamegoldáshoz }\end{array}$ & $\begin{array}{l}\text { Központi kontroll megerösített } \\
\text { helyi igazgatással } \\
\text { Magas politikai stabilitás } \\
\text { a vétószereplök számának } \\
\text { növelése révén }\end{array}$ & $\begin{array}{l}\text { Bünbakáthárítás központi } \\
\text { szintröl a helyire } \\
\text { A bevételek és a kiadások } \\
\text { közötti összhang hiánya } \\
\text { A központi és a helyi szintek } \\
\text { menedzselhetöségének } \\
\text { a nehézsége }\end{array}$ \\
\hline $\begin{array}{l}\text { Demokratikus ellenőrzés: } \\
\text { átláthatóság, politikai felelős- } \\
\text { ség, döntési felelősség, állam- } \\
\text { polgári/használói részvétel }\end{array}$ & $\begin{array}{l}\text { A térbeli közelség növeli a } \\
\text { részvétel esélyét, javuló átlát- } \\
\text { hatóság, elszámoltathatóság }\end{array}$ & $\begin{array}{l}\text { Korrupció, a közjavak } \\
\text { kisajátításának növekvő } \\
\text { esélye }\end{array}$ \\
\hline $\begin{array}{l}\text { Egyenlöség: } \\
\text { teljesítménybeli azonosság, } \\
\text { egyenlö bánásmód }\end{array}$ & $\begin{array}{l}\text { Rugalmas alkalmazkodás a } \\
\text { helyi preferenciákhoz és körül- } \\
\text { ményekhez }\end{array}$ & $\begin{array}{l}\text { Teljesítménykapacitások } \\
\text { különbsége, kétség az életfel- } \\
\text { tételek azonosságát illetően, } \\
\text { jogbizonytalanság, eltérő } \\
\text { eljárások }\end{array}$ \\
\hline
\end{tabular}

Forrás: Grohs, Stephan-BogumiL, Jörg-KunLmann, Sabine: Überforderung, Erosion oder Aufwertung der Kommunen in Europa? Eine Leistungsbilanz im westeuropäischen Vergleich. Zeitschrift für Public Policy, Recht und Management, 2012/1, 125-148.

Többszintű rendszerek esetében közpolitikai szempontból a decentralizáció beavatkozás a funkcionális szerkezetbe és az intézményi logikába. Ez a közpolitika azon típusa, ${ }^{15}$ melyet a politika politikájának is neveznek (polity policy), s amely sajátos irányítási problémákat generálhat.

A politikai-igazgatási rendszeren belül elemzés tárgyát képezhetik az intézményi változások (institutional evaluation). Ezt követheti a közigazgatás hatékonyságának az értékelése (performance evaluation), míg a harmadik lépés a politikai-igazgatási rendszeren kívüli, távolabbi hatások számbavétele (outcome evaluation).

A három lépés mindegyikében a beavatkozó tényezők száma és az oksági problémák egyre nagyobbak. Ennek következtében egyre nehezebb pontos, megfigyelhető változásokat rendelni a reform eszközökhöz, és gyakran lehetetlen az egyes mechanizmusok hatásait izolálni. Mi több, a különböző érdekhordozók perspektívája és elkötelezettsége függvényében a teljesítmény értékelése és mérhetősége szintén változó lehet.

A decentralizációs politika intézményi szerkezetre és a teljesítményre gyakorolt hatásainak a felmérésére számos analitikai keret ismeretes. A multidimenziós megközelítés magában foglalja a decentralizációval kapcsolatos különböző jövőképeket és a teljesítménnyel kapcsolatos elvárásokat. Az egyik lehetséges metódus, amikor a közpolitika a maga által meghatározott célokhoz képest vizsgálja azt, hogy az egyes reformcélok (költségtakarékosság, minőségi javulás stb.) mennyiben valósultak meg.

15 Politics a politika szó mindennapi, gyakran negatív értelmében használt kifejezése, míg a polity politikai rendszert, elsősorban struktúrákat és intézményeket jelent. A policy kifejezés a kormányzati politika tartalmára, a különböző szakpolitikákra (kulturális politika, szociálpolitika, agrárpolitika stb.) utal. 
A másik módszer az, amikor a társadalomtudományokból merítenek indikátorokat a hatások felmérésére. Scharpf ${ }^{16}$ modern demokráciaelmélete alapján az intézményi reformok hatása mérhető az input legitimáció (demokratikus ellenőrzés, elszámoltathatóság, átláthatóság) az output legitimáció (hatékonyság, hatásosság) és a throughput legitimáció (horizontális/vertikális koordináció) révén.

2. táblázat. Az önkormányzati teljesítmény mérése a decentralizációs reformok alapján

\begin{tabular}{|l|l|}
\hline \multicolumn{1}{|c|}{ Teljesítménykritérium } & \multicolumn{1}{|c|}{ Lehetséges dimenziók/indikátorok } \\
\hline $\begin{array}{l}\text { Output legitimáció: } \\
\text { eröforrások, költségek, output }\end{array}$ & $\begin{array}{l}\text { Költségek, erőforrások (személyi, idő, } \\
\text { finanszírozás) elért megtakaritások } \\
\text { Produkált output } \\
\text { Kapcsolat input és output között } \\
\text { Szakmai minőség, standardok megtartása } \\
\text { Jogi korrektség, peres eljárás } \\
\text { Állampolgári/fogyasztói közelség/szolgáltatási jogi minőség/célok elérése } \\
\text { minőség } \\
\text { Hatékonyság/hatásosság, célcsoport } \\
\text { lefedettsége }\end{array}$ \\
\hline $\begin{array}{l}\text { Throughput legitimáció: } \\
\text { vertikális és horizontális koordináció }\end{array}$ & $\begin{array}{l}\text { Részlegek közötti koordináció } \\
\text { Települések közötti koordináció } \\
\text { Szintek közötti koordináció } \\
\text { Kontroll, beavatkozás „felülröl” } \\
\text { Ellenállás/teljesítés „alulról” }\end{array}$ \\
\hline Input legitimáció: & $\begin{array}{l}\text { A helyi önkormányzat részvétele } \\
\text { Állampolgári részvétel, használói demokrácia } \\
\text { Külső transzparencia }\end{array}$ \\
\hline
\end{tabular}

Forrás: Kunlmann, Sabine-Wollmann, Helmut: The Evaluation of Institutional Reforms at Subnational Government Levels: A Still Neglegted Research Agenda. Local Government Studies 2011/5, 490 .

\section{2. Önkormányzati modellek, nemzeti sajátosságok}

A komparatív reformelemzések ${ }^{17}$ célja a decentralizáció számára kedvező politikai-intézményi feltételek feltárása és a közpolitikai célok alapján kifejtett hatások vizsgálata. A megvalósított reformokra, azok sajátosságaira országspecifikus (igazgatási tradíciók, önkormányzati rendszer), szakpolitikai (a delegált feladatok jellege), aktorspecifikus és külső tényezők (pénzügyi nyomás) kölcsönös kapcsolata, egymásra hatása van befolyással.

A múltból örökölt, történelmileg megszilárdult intézményi szerkezet és igazgatási tradíció döntő faktor a reformok sikere vagy kudarca tekintetében. A politikailag és történetileg is eltérő kontextusok a decentralizációs reformoknak sajátos hatásokat

16 Scharpf, Fritz, W.: Governing in Europe - Effective and Democratic? Oxford University Press, New York, Oxford, 1999.

17 Kunlmann, Sabine-Wollmann, Hellmuth: Introduction to Comparative Public Administration - Administrative Systems and Reforms in Europe. Edward Elgar, Cheltenham, UK, 2015. 
kölcsönöznek. Míg a külső hatások nemzetközileg is hasonló reformtörekvésekhez vezethetnek, addig a megvalósítás eredménye és az intézményi változások mikéntje az egyes országokban - lényegében - az országspecifikus politikai, intézményi és kulturális jellemzők függvénye.

A történelmi institucionalizmus ${ }^{18}$ hangsúlyozza a múltbeli intézményi választások és az útfüggőség (path dependency) jelentőségét, melyek determinálják a jövőbeli fejlesztéseket. Az intézményépítés folyamata meghatározott a már létező intézményi szerkezet által, mely történelmi háttér relatíve stabil, és egyike azon döntő tényezőknek, melyek a fejlődést a meghatározott úton viszik tovább. Éppígy, a későbbi politikai választások is determináltak a politika legalitása és a politikai aktorok múltból megörökölt kognitív elképzelései által. A történelmi institucionalizmus aláhúzza a reformok korlátozott voltát, a szük keresztmetszetet, javasolván az inkább fokozatos, inkrementalista, mintsem kiterjedt és nagyszabású intézményi változásokat.

Az önkormányzatok funkcionális, területi és a politikai sajátosságai hatnak a decentralizációs eljárásokra és effektusokra. Így például, ha egy országban, központihelyi viszonylatban a területi szint ún. egységes rendszerként funkcionál, egy szervezetben látva el az önkormányzati és az állami feladatokat, akkor ez nehezítheti a decentralizációt. Éppígy, ha több politikai párt és szereplő érintett a decentralizációs döntésekben, az szintén lassíthatja a folyamatot. Új funkciók helyi szintre történő telepítése függhet az önkormányzat területi jellemzőitöl, ${ }^{19}$ attól, hogy képes-e feladatait demokratikusan ellátni, s a hivatali szervezetet is megfelelően müködtetni.

Az önkormányzati rendszerek között különbséget lehet tenni abból a szempontból, hogy az állami és az önkormányzati szervek feladataikat elkülönülve vagy szorosan együttmüködve hajtják végre. Az első igazgatási típus hagyományosan a brit és skandináv országokban jellemző. Ezzel szemben a kontinentális Európában az egységes rendszer honosodott meg, ami azt jelenti, hogy az állami és az önkormányzati feladatokat integrált szervezeti keretben (Németország, Ausztria) látják el.

Bevett tipológia az önkormányzati feladatok jellege és tartalma alapján történő osztályozás. Az európai önkormányzatoknál a feladatokat illetően a generális kompetencia, az általános felhatalmazás elve érvényesül, mely szerint az önkormányzat elláthat minden olyan helyi közfeladatot, melyet jogszabály kifejezetten nem utalt más állami szerv hatáskörébe. A brit önkormányzatoknál az ultra vires alapelv dominált egészen 2010 -ig, ${ }^{20}$ ami azt jelentette, hogy adott hatáskör gyakorlása parlamenti felhatalmazáson alapult.

Lényeges eltérés lehet az önkormányzatok alkotmányos státusza és feladat-, hatásköre között. Németországban, Svédországban ${ }^{21}$ erős az alkotmányos jogállás, $\mathrm{s}$ széles a feladatok köre is. Ezzel szemben az Egyesült Királyságban gyenge a

18 Az új institucionalizmus egyik iránya, mely szerint a politikai folyamatokat nem pillanatfelvétel-szerüen kell tanulmányozni, hanem szekvenciálisan, vagyis az események egymásutánja szükséges a megértésükhöz.

19 Fragmentált, kistelepüléses szerkezet esetén az intézményi kapacitás határt szab a feladatok delegálásának.

20 2011-ben került elfogadásra a Localism Act, mely szerint: „A local authority has power to do anything that individuals may do" (Part one, chapter1).

21 Asvéd önkormányzatok pénzügyi autonómiája a legnagyobb, mivel bevételük $54 \%$-a saját bevétel. JoHANSSON, Tobias: Municipial Contracting Out: Governance Choices, Misalignment and Performace in Swedish Local Government. Financial Accountability and Management, 2008/3, 3. 
helyhatóságok alkotmányos beágyazottsága, ugyanakkor jelentősek a feladataik (amelynek értékelésekor viszont figyelembe kell venni az egy önkormányzatra jutó kiugróan magas lakosságszámot is, ami az észak-európai országokra jellemző). ${ }^{22}$

Az önkormányzat területi sajátosságai fontos intézményi feltételt jelentenek a kapacitás és a működőképesség szempontjából. A területi jellemzők alapján alapvetően két nagy modell határolható el, az észak-európai és a dél-európai. Az északi államokban (Svédország, Dánia) területileg nagyobb léptéket ${ }^{23}$ fednek le az önkormányzatok. Az Egyesült Királyság önkormányzati rendszere is ebbe a kategóriába sorolható. Dél-Európában (Franciaország, Olaszország) az önkormányzati struktúrát a kistelepülések dominanciája ${ }^{24}$ jellemzi. Az európai szövetségi államokban vegyes megoldások találhatók: Svájc, Ausztria, valamint egyes német tartományok (Baden-Württemberg, Schleswig-Holstein), valamint a keleti tartományok az északi, míg Észak-Rajna-Vesztfália és Hessen tartományok inkább a dél-európai mintát követik.

A helyi önkormányzatok politikai profilját több tényező határozza meg. Így a képviseleti vagy a közvetlen demokrácia jellege, a képviselö-testület és a végrehajtó szerv viszonya (monista vagy duális), valamint a végrehajtó szerv választásának módja (közvetlen vagy közvetett). A képviseleti demokrácia a meghatározó az Egyesült Királyságban, Franciaországban és Svédországban. A közvetlen demokrácia érvényesül, helyi referendumok formájában is Svájcban, a német tartományokban, Olaszországban.

A monista rendszerekben minden kompetencia (döntés, végrehajtás, ellenörzés stb.) a választott testület vagy az adott szakágazatot irányító bizottság kezében van. A struktúra sajátosságainak megfelelően a szervezetben nincs erős polgármester, jellemző a szektorális elkülönülés, és hiányzik a markáns politikai és szakmai vezetés. A duális rendszerekben a feladat- és hatáskörök megoszlanak a testület és a végrehajtó szerv (bizottság, polgármester) között, a végrehajtó testületnek önálló jogosítványai vannak (Franciaország, Németország, Portugália stb.). Az erős polgármesteri modellt alkalmazó országokban (Franciaország, Olaszország) a közvetlen választásnak köszönhetöen tovább növekedett a helyi vezető politikai súlya.

A politikai hatalom, befolyás kiterjesztésének sajátos formája a mandátumok halmozása (Franciaország), illetöleg a patrónus-kliens jellegü kapcsolatok széles körü alkalmazása (Olaszország, Görögország). Mindez nem kívánatos mellékhatásként a helyi szint „gyarmatosítását” eredményezheti, annak minden negatív következményével.

22 A gazdasági, pénzügyi válság nyomán számos önkormányzati feladatot elvontak az önkormányzatoktól. Lásd erre vonatkozóan: Lowndes, Vivien-GaRdneR, Alison: Local Governance under the Conservatives: Super-Austerity, Devolution and the 'Smarter State'. Local Government Studies, 2016/3, 359-361.

23 Az összevonások, a területi integrációk elsődlegesen a működőképesség és a költségtakarékosság szempontjait szolgálták.

24 A latin államokban az erős történelmi, társadalmi, politikai, intézményi, kulturális hagyományok miatt nem hajtottak végre integrációt. 


\section{A jóléti szolgáltatások decentralizációja}

A francia decentralizáció a közfeladatoknak a szintek közötti átszervezése tekintetében sajátos esetet képvisel. Más európai országokkal szemben itt a decentralizáció sohasem jelentett olyan stratégiát, mely valamiféle „közkívánat” révén ${ }^{25}$ került megvalósításra. A kezdet a nyolcvanas évekig ${ }^{26}$ nyúlik vissza, amikor a politikusok megpróbálták a „kör négyszögesítését”27 megvalósítani. Az elképzelés az volt, hogy a republikánus eszmét ${ }^{28}$ megtestesítő központi állam egyes feladatait át kell adni a szubnacionális szinteknek, mivel a feladatok megosztása révén nemcsak a közszolgáltatások hatékonysága növelhetö, de a közigazgatás is közelebb kerül az emberekhez. A jóléti rendszer területi reformját két lépésben, a decentralizációt előíró törvények alapján, 1982-1986 és 2003-2004 között hajtották végre.

A jóléti ellátások központi intézményét jelentő jövedelemtámogatási rendszerrel (Revenu minimum d'insertion - RMI ${ }^{29}$ kapcsolatos feladatok teljes átadása a megyei önkormányzatok képviselö-testületeinek ${ }^{30}$ (conseils généraux) 2003-ban azt jelentette, hogy a jogalkotó lezárta a közös kormányzás 1988 óta tartó szakaszát.

1988 és 2004 között az RMl-feladatok az alábbiak szerint oszlottak meg az állam szervei és a képviselö-testületek között:

a) A prefektus, mint az állam területi képviselöje és a képviselö-testület ${ }^{31}$ elnöke közösen gyakorolta a tervezési és szabályozási funkciókat. A kooperáció eredményeként létrejött befogadó szociális szolgáltatás (plan départmental d'insertion - PDI) program közös, állami-megyei bizottság (commission départmentale d'insertion - CDI) keretében müködött.

b) A prefektus hatáskörébe tartozott a program részét alkotó jóléti és a szociális feladatok finanszírozása. A testületnek az előző évi költségvetés legalább 17\%-a erejéig kellett a kiadásokhoz hozzájárulnia.

c) Emellett a prefektus ellátta a jóléti támogatással kapcsolatos adminisztratív feladatokat is, így - többek között - döntött a szociális segélyekkel kapcsolatos kérelmekben.

25 Szemben más európai államokkal, a francia decentralizáció felülröl induló kezdeményezés volt.

26 A szubnacionális szintek erősítését célzó törekvések 1981-ben kezdődtek, melyek azonban a különböző funkcionális területeken a kormányzati szintek közötti magas fokú vertikális integrációval párosultak.

27 A klasszikus etatista államszerkezet megváltoztatására irányuló törekvések hiábavalóságára utal a kitétel.

28 A nemzet egységes, az állam a közérdeket szolgálja. A közigazgatás erős, központosított, hierarchikus, depolitizált, elszámoltatható és ellenőrzött. A személyi állomány képzett, szakszerű, szakmai csoportokba (corps) szervezett.

29 Jövedelemminimum-támogatást nyújtó jóléti ellátás. Az igénylés feltételei: 25 év feletti életkor vagy gyermekes családi állapot, munkavállalás az első kifizetést követő 3 hónapon belül, francia lakóhely, illetve nem uniós polgárok esetében legalább 5 éves franciaországi lakhatás, a kérelmező nem tanuló, nem egyetemista, nincs munkatapasztalata, nem házas, nem él életközösségben vagy partneri kapcsolatban olyannal, aki nem felel meg a feltételeknek. 1988-ban Jean-Michel Belorgey, a Michel Rocard-féle szocialista kormány tagja vezette be.

30 A megyei önkormányzat (département) szervezetét három elem alkotja: a képviselö-testület, az elnök és a hivatal.

31 A megye államigazgatási müködési terület és területi önkormányzat is. Ez utóbbi választott testülettel bír, de önálló végrehajtó szervezettel 1982-ig nem rendelkezett, e feladatokat a prefektus látta el. Ennek nyomán megyei szinten az államigazgatás és a területi önkormányzat egy szervezeten belül jelenik meg. 
d) A képviselö-testületnek szintén részt kellett vállalnia az RMI szociális szolgáltatásainak biztosításában.

A nyolcvanas években a szegénységgel kapcsolatban kibontakozó társadalmi párbeszéd, valamint a hosszú távú munkanélküliség kedvezőtlen adatai a francia szociális ellátórendszer egyre erősebb kritikáját eredményezték. Kétségessé vált ugyanis, hogy a rendszer képes-e az új kihívásokra megfelelően reagálni. A jóléti ellátások ügye kezdetektöl fogva politikailag kiemelt szerepet játszott a vitában.

Az emelkedő költségek és az ezzel járó kockázatok miatt végül a szocialista kormány arra az elhatározásra jutott, hogy nem adja át a nemzeti szolidaritás e fontos feladatát a megyéknek, mivel az egyenlőség (égalité), mint az állam hagyományos republikánus imperatívusza kizárta a feladatok teljes körü decentralizációját. A megoldást a központi és a megyei szervek együttmüködése jelentette.

A helyzet bonyolultságát mutatta, hogy a munkaerőpiaci integrációért felelös prefektus tevékenysége nagyban függött a megyei képviselö-testületek támogatásától. Ezek ugyanis a nyolcvanas évektől kezdve meghatározó szerepet játszottak a helyi szintủ jóléti politikában, kiépítették saját ellátórendszerüket, s hálózatokat hoztak létre a szociális szolgáltatásokat nyújtó partnerekkel, más szervezetekkel.

Az állampolgári egyenlőség érvényesítése, valamint az állami és szubnacionális szervek közötti intenzív kooperáció a közös kormányzás elsődleges prioritása volt. A gyakran megfogalmazódó kritikák viszont a rendszer komplex, bürokratikus karakterét hangsúlyozták, átláthatóságot, egyszerüsítést követelve. A kényszerü együttműködés, a jóléti ellátásokkal kapcsolatos hatáskörök világos meghatározásának hiánya, a „közös irányítás” azonban a költségek növekedését eredményezte és akadályozta a munkanélküliek integrálását.

Az RMI-program a kezdetek óta a szociális ügyfelek támogatására és aktivitásuk elősegítésére helyezte a hangsúlyt, azonban a társadalmi integrációval kapcsolatos törekvések az 1988-tól 2003-ig tartó időszak alatt kevésbé érvényesültek, ${ }^{32}$ mivel az egyéni integrációt elősegítő szerződéseket csak ritkán alkalmazták.

A hiányosságok, a meglehetősen vegyes gyakorlati tapasztalatok, valamint a folyamatos bírálatok nyomán a konzervatív Raffarin-kormány ${ }^{33}$ végül a 2003 decemberében elfogadott törvénnyel megreformálta és decentralizálta az RMI-rendszert.

2004 januárjától a megyei képviselö-testület az RMI-program kizárólagos felelősévé vált. A 2003-as decentralizációs törvény rögzítette, hogy a jövedelemtámogatási rendszer a megyei testület kompetenciája, így minden döntés az elnök ${ }^{34}$ és a hivatali szervezet vezetőinek a kezébe került. A befogadó szociális szolgáltatás tervezése és végrehajtása mellett az egyéni támogatásban részesülőkkel kapcsolatos kompetenciák is a képviselö-testület hatáskörébe kerültek. Ezzel a megyék és érdekszövetségük (Assamblée des départements de France - ADF) régi óhaja vált valóra.

\footnotetext{
32 Az integrációs megállapodások száma az RMI ügyfeleinek alig $50 \%$-át érte el.

33 Jean-Pierre Raffarin: 2002. május 6. - 2005. május 31.

34 Az elnök hatáskörébe kerültek az egyéni RMI-kérelmekkel kapcsolatos ügyek is.
} 
A változások ellenére azonban a költségvetési feltételek megteremtésével és a jóléti közszolgáltatások (azonos) színvonalával kapcsolatos régi-új viták nem kerültek le a napirendröl. Mivel a munkanélküliek aránya és a hosszú távú munkanélküliek száma jelentősen eltérő volt az egyes megyék között, felvetődött, hogy sérül a munkanélküliség területileg is kiegyensúlyozott kezelésének és az azonos szintü közszolgáltatások biztosításának követelménye.

A jogalkotó eltörölte a megye pénzügyi hozzájárulására vonatkozó szabályt, ezzel is hangsúlyozva a testület autonómiáját. Emellett bevezettek egy új típusú integrációs szerződést (contract d'insertion-revenu minimum d'activité - Cl-RMA), ${ }^{35} \mathrm{~s}$ létrehozták az integrációs hivatalnok (référent d'insertion) posztját, melynek feladata a képviselö-testület és a köz- és magánszervezetek közötti együttműködés elősegítése, a koordináció javítása volt. Ily módon az RMI a munkaerőpiaci problémák megoldásában meghatározó szerepet kapott.

Az intézményi és közpolitikai reform következtében a megyéknek tehát nemcsak az intézményi adaptáció, hanem az alkalmazott új eszközök, módszerek, eljárások kettős kihívásával kellett szembenéznie.

\section{Teljesítményeffektusok: személyzet, eröforrások, szakmai minőség, jogszerüség, fogyasztói orientáció}

A 2003-as decentralizációs törvény a pontos szám meghatározása helyett csak arról rendelkezett, hogy a megyéknek ugyanannyi munkatársat kell kapniuk az RMIfeladatok ellátására, mint amennyivel az állami szervek korábban rendelkeztek. A prefektus feladata volt a személyi állomány létszámának meghatározása.

A végrehajtás késedelme mellett a módszer számos konfliktust eredményezett a kormányzati szintek között. 2007-re 627 státuszból csak 387 került átadásra, azon túl, hogy egyes megyékben a teljes személyi állományt, míg másokban csak annak a felét sikerült feltölteni. Emellett az átadott személyzet és az ügyfelek száma közötti kapcsolat is erősen hullámzott ${ }^{36}$ az egyes megyék között. Nem volt meglepő tehát, hogy a megyék $72 \%$-ában további munkatársak felvétele vált szükségessé, mely eljárást csak 2005-re tudták befejezni. A trend folytatódott egészen 2009-ig, amikor az RMI-t integrálták egy hasonló célú ellátásba, az RSA-ba. ${ }^{37}$

$A z$ állam által biztosított pénzügyi kompenzáció szintén nem bizonyult megfelelőnek. A megyék teljes bevétele 2003 és 2008 között az egy lakosra számított évi 617 euró átlagról 999 euróra növekedett. Az állam kiegészítést nyújtott a jövedéki adó $^{38}$ révén befolyt forrásokból, majd 2006-tól további kompenzációt ${ }^{39}$ vezetett be a társadalmi integráció elősegítése címén.

35 Jövedelemminimumot biztosító megállapodás.

36 Míg Bouches-du-Rohne megyében 4300 RMl-ügyfél jutott egy átadott státuszra, addig ez a szám 878 volt Gers megyében.

37 Revenu de Solidarité Active - RSA, francia jóléti kezdeményezés a munkába való visszatérés akadályainak leküzdésére. 2009. június 1-én vezették be.

38 Taxe intérieure sur lés produits pétroliers - TIPP.

39 Fonds de mobilisation départmentale pour l'insertion - FMDI. 
A jelentős erőfeszítések ellenére a pénzügyi kompenzáció nem volt elegendő a reformcélok eléréséhez. A francia kormány a többet kevesebből (faire mieux avec moins) elv alapján járt el, amikor a program finanszírozásáról döntött. A 2004-es pénzügyi törvény abból indult ki, hogy a többletköltségek fedezetét egy adó, nem pedig címzett központi támogatás biztosítja majd. Ez látszólag jó megoldás volt, ugyanakkor ez az adóforrás semmiféle kapcsolatban nem volt a munkanélküliség alakulásával, valamint nem kompenzálhatta az instabil gazdaságból fakadó további - nehezen megbecsülhető - kockázatokat.

A költségek emelkedéséhez szervezeten belüli tényezők is hozzájárultak. A megyék a korábbi időszakhoz képest is nagyobb figyelmet fordítottak feladataik magas szintủ ellátására, a minőségi szolgáltatásra a technikai háttér, valamint a szervezési folyamatok és eljárások korszerüsítése révén. Mindez a tranzakciós költségek növekedését vonta maga után.

A kedvező gazdasági kilátások alapján a legtöbb képviselö-testület meg volt győződve arról, hogy az állami szerveknél hatékonyabban képes majd menedzselni az integrációs és jóléti programokat. A jövedéki adóból befolyt összegek azonban nem emelkedtek olyan gyorsan, mint az RMI-program kiadásai, így 2011-re jelentős, 1,9 milliárd euró finanszírozási hiány keletkezett. Mindez azt jelentette, hogy az állami kompenzáció csak a költségek $74 \%$-át fedezte. Ezen tény következménye nemcsak a megyei források csökkenése, hanem a pénzügyi mozgástér jelentős beszűkülése is volt. Sőt a feladatok folyamatos átadása nyomán, 2003 után a jóléti kiadások újabb növekedésével kellett számolni.

A kedvezőtlen feltételek ellenére azonban a szolgáltatások színvonala alig csökkent, ami a területi szervek rugalmas alkalmazkodását igazolta. Némi visszaesés ${ }^{40}$ csak a gyengébb gazdasági háttérrel rendelkező megyék esetében volt érzékelhető.

A jóléti, szociális ügyekben alkalmazott eljárások megfeleltek a jogszabályi követelményeknek is. Változást csupán az első fokú döntések ellen benyújtott fellebbezések számának növekedése mutatott. Ez azonban nem a szolgáltatási szint romlását mutatta, csupán azt jelezte, hogy számos megye szigorúbb eljárás ${ }^{41}$ vezetett be a csalások kiszürése végett.

A szakmai minőség vonatkozásában az átmenet kevésbé volt zavarmentes. Az egyik legjelentősebb változást az egyéni menedzser kötelező alkalmazása jelentette, akinek feladata a kapcsolattartás volt. A legtöbb megye azonban az ügyfeleket a kérelmek alapján speciális csoportokba sorolta a szolgáltatások standardizálása és az egyéni támogatás erősítése céljából. A kedvezményezettek tájékoztatásával a munkaerőpiaci integráció folyamatát kívánták gyorsítani.

A jóléti szolgáltatások reformja körében érintett szervezetek eljárásuk során eltérő szempontokat hangsúlyoztak. Voltak, akik elsősorban a szolgáltatások magas költségeit, s az ezzel járó társadalmi áldozatvállalást emelték ki. Mások a szociális integráció folyamatába kívánták az ügyfeleket bevonni, egyénre szabott eljárások és gyors munkaerőpiaci integráció révén.

40 Ez gyakorlatilag az ügyintézés késedelmét jelentette.

41 A pénzügyi önállósága felértékelte a hatékonyság szempontját, s a jogtalan kifizetések megelőzése végett bevezették az egyéni kérelmek fokozott ellenőrzését. 
A számtalan szakmai, intézményi, eljárásbeli, szemléletbeli különbség nyomán az egyes megyék közötti különbségek 2003-at követően jelentősen megnőttek. Következésképpen a szociális intervenciók területén a francia politikai és igazgatási kultúrában oly mélyen gyökerező egyenlő bánásmód elve egyre inkább kérdésessé vált.

\section{Rendszerhatások: horizontális, vertikális koordináció, elszámoltathatóság, legitimáció}

A decentralizáció kifejezett törekvése volt - egyebek mellett - a szubnacionális szintek közötti koordináció javítása, az intézményi átfedések megszüntetése. Az RMI decentralizálása lehetőséget jelentett a megyék számára a helyi szervekkel való kapcsolat új alapokra helyezésére. 2003-ban azonban a jogalkotó nem csökkentette az intézményi szereplők számát, így a megyék mellett öntevékeny és jótékonysági szervezetek, CAF-hivatalok ${ }^{42}$ stb. is részt vettek a jóléti feladatok megvalósításában.

A francia alkotmány rögzíti, hogy minden helyi és területi hatóság illetékességi területén szerepet vállalhat a közügyek, így a szociális ügyek intézésében is. Ez az alapelv érintetlen maradt, jóllehet a 2003-as decentralizációs törvény kiemelte a megye irányító (chef de file) szerepét a társadalmi integráció területén. A megyei önkormányzati képviselő-testületek élve a felhatalmazással a politikai prioritások meghatározása s a már létező megállapodások felülvizsgálata mellett, csak a partnerek közötti - meglehetősen egyenlőtlen - feladatmegosztást tudták véghezvinni. Az elvárt transzparencia foka alacsony maradt.

A szerződéses megállapodások előtérbe helyezése - elméletileg - egy további jó megoldást jelenthetett volna a szintek közötti átfedések csökkentésére. A megyék azonban nem hivatkozhattak formális ellenőrzési jogkörükre a településekkel szemben, mivel ez utóbbiak ragaszkodtak szabadon vállalt feladataikhoz. A helyi jóléti szolgáltatások szerződéses gyakorlata ezért inkább növelte, mintsem csökkentette a koordináció iránti igényt.

Hasonlóan a vertikális koordináció sem vált könnyebbé a decentralizáció nyomán. A kooperáció intenzitása az állam területi szervei és a megyék között alapvetően megváltozott 2004 után. A képviselő-testületek többségének az állam helyi szerveivel való kapcsolata minimalizálódott. Következésképpen a decentralizáció nem járult hozzá az egyes szintek közötti összefonódás szétválasztásához. Az új törvényi felhatalmazás alapján, mely az ügyfelek gyors munkaerőpiaci integrációját írta elő, a formális kooperáció helyébe a dekoncentrált szervekkel való önkéntes interakció lépett.

A decentralizációs törvény autonóm döntési lehetőséget kívánt adni a képviselőtestületeknek az RMl-ügyek tervezése, döntése és végrehajtása, valamint a járulékos szociális szolgáltatások biztosítása terén is. Ez a törekvés azonban látszatintézkedés maradt két okból is: egyrészt a központi kormány 2003 után is intenzíven szabályozta a szociálpolitikát. Ez kiterjedt annak tartalmára, a végrehajtásra, vala-

42 A Caisse Allocations Familiales - CAF, kormányzati szervek, melyek a különböző területeken (közszolgáltatás, iskoláztatás, egészségügy stb.) nyújtanak támogatást a rászorulóknak. 
mint a szociális adminisztráció szervezetére és más szociális szolgáltatásokra is. Ennek következtében a képviselö-testületek inkább az állam ügynökeinek, mintsem autonóm döntéshozóknak bizonyultak. Emellett az RMI-vel kapcsolatos politika és költségvetési tervezés - a decentralizációt megelőző időszakhoz hasonlóan - a megyék végrehajtó szerveinek hatáskörében maradt.

Meglehetősen kijózanítóak voltak a részvétellel kapcsolatos tapasztalatok is. Az ügyfelek bevonása a szociális döntésekbe a megyék többségénél kivételes eset volt. Az a tény, hogy napjainkban a jövedelemtámogatásban részt vevő ügyfelek 85\%-a az ún. interdiszciplináris munkacsoportok keretében részt vesz a helyi tervezésben, nem a megyék tanulási folyamatának az eredménye, hanem a 2009-től hatályos jogszabályi előírások következménye. Végeredményben tehát a képviselötestületek nyitottságának és elszámoltathatóságának az erősítését célzó decentralizációs elképzelések hatástalannak bizonyultak.

\section{Konklúzió: a decentralizáció sikertelenségének oka}

A neoinstitucionalista nézőpont ${ }^{43}$ szerint a közfeladatok decentralizálása nemcsak a hatékonyság növelését eredményezheti, de segítheti az elszámoltathatóság követelményének az érvényesítését is. A francia decentralizáció a „távolból történő irányítás" (avec command à distance) sajátos válfajaként értelmezhető. A kormány a strukturális változások nyomán visszanyerte irányítási képességét: a decentralizáció révén, paradox módon egyfelől funkcionálisan megerősítette a helyi szerveket, meghatározta azok feladatát, felelősségét, másfelöl pedig lokális állami hivatalokat, ügynökségeket intézményesített.

A távolból történő irányítás politikája feltételezte a közkiadások csökkenését, a szubnacionális szintek versenyét az egyre korlátozottabb központi forrásokért. A második decentralizációs törvény hatásaként ezek a várakozások azonban csak részben igazolódtak. A strukturális/intézményi és közpolitikai reformok időszakos egybeesése túlterhelte a megyéket, így a nagy áttörés (big-bang) helyett csak fokozatos változások következtek be, szerény hatékonysági nyereséggel.

Az RMI decentralizációját követően a jóléti ellátások és a társadalmi integrációt szolgáló szociális szolgáltatások kiadásai megemelkedtek. Ennek oka elsősorban a személyi állomány bővítése volt, mivel jogszabály írta elő az ún. egyedi ügykezelést (réferent d'insertion) és a közfoglalkoztatás új szerződéses (contract d'insertionrevenu minimum d'activité) rendszerének alkalmazását. Ezek a követelmények olyan többletkiadásokat eredményeztek, melyek korábban nem voltak előreláthatóak. A megyék egy része ${ }^{44}$ a szolgáltatások színvonalának a fenntartása és a többletfeladatok ellátása érdekében új munkatársakat volt kénytelen alkalmazni.

A koordinációs problémákat elsődlegesen az okozta, hogy az állam nem biztosította irányítási funkciójának az érvényesülését, s megyei szinten korlátozta a tár-

43 March, James G.-Olsen, Johan P.: Rediscovering Institutions. The Organizational Basis of Politics. The Free Press, New York, 1989, 96.

44 Gironde megyében 24, míg Seine-Maritime megyében 90 fő alkalmazására került sor. 
sadalmi integrációval kapcsolatos politikáját. 1990 óta a képviselö-testületek hatásköreik csökkenése ellenére a nagy jóléti programok felelösei maradtak, megfelelö állami finanszírozás nélkül. Érdemi autoritással azonban nem rendelkeztek az integrációs politika irányvonalának, tartalmának meghatározása terén, jelentősen kiszolgáltatva más intézményi partnerek (települési önkormányzatok, állami szervek, egyesületek stb.) együttmüködési hajlandóságának. A pénzügyi források elosztása és a feladatok meghatározása is különböző volt az egyes szereplök között, így az érdekeltek kiugróan magas száma és eltérő háttere nem tette lehetővé a kooperációt. ${ }^{45} \mathrm{~A}$ szerződéses megállapodások rendszere nem bizonyult funkcionálisan azonosnak az irányítás formális hierarchiájával.

Az is hamarosan nyilvánvalóvá vált, hogy a nagyszámú helyi szervezet nem képes a társadalmi integrációval kapcsolatos feladatait a központi szervek, illetve azok helyi ügynökségei támogatása nélkül megvalósítani. Ezért újjáélesztették kapcsolataikat az állami szervekkel, s a kezdeti informális kooperáció hamarosan hivatalos formát ${ }^{46}$ öltött. Végeredményben a decentralizáció nem járt a vertikális hierarchia megbontásával, az egyik összefonódó struktúra egy másikkal lett helyettesítve.

A szubnacionális szinteknek a társadalmi integrációval és kohézióval kapcsolatos feladataira vonatkozó részletes szabályozás, valamint a decentralizációs reform nem kielégítő megtervezése intézményi értelemben a célokkal ellentétes hatásokkal járt. 2003 után a képviselő-testületek jelentős erőfeszítései ellenére a költségvetési és személyi állománnyal kapcsolatos problémák akadályozták az új feladatok végrehajtását. Ez tovább növelte a szociális ellátások és társadalmi szerepvállalás differenciáit a megyék között, és felerősítette azt az igényt, hogy újra kell gondolni az állam szerepét az egyenlő szolgáltatásokhoz való jog biztosítása érdekében. A Balladur-bizottság is 2009-ben ezt a célt tartotta a legfontosabbnak.

2008 után a francia állam további radikális lépéseket tett a területi reform ${ }^{47}$ érdekében. Az urbanizált régiókban levő megyék megszüntetése révén nagyvárosi régiók létrehozatalát javasolták, majd 2010-töl a törvény lehetővé tette a megyék és a régiók fúzióját, és az ún. nagyvárosi pólusok kialakítását. 2016-ra megvalósult a régiók számának a csökkentése ${ }^{48}$ is, ami többek között a régiók feladat- és hatáskörét jelentősen növelte a megyék rovására.

A megyék, illetőleg a megyei szövetség erős ellenállása a területi reformokkal szemben azonban világosan jelezte a döntéshozók számára, hogy a sürün átszőtt, vastag intézményi hálót, ${ }^{49}$ a francia területi igazgatás rendszerét nagyszabású refor-

45 Az együttmüködés feltételezi a bizalmat, míg a bizalom feltételez valamilyen szabályszerűséget, rendet. Ha nincs egyetértés az ügyek fontossága, a releváns ismeret, illetve a különböző célok prioritása tekintetében, a hierarchikus állami irányítás visszavonulása esetén a kormányzás új módjának a megtalálása a helyi aktorok kezében van.

46 Az együttmüködés különösen szorossá vált a Nemzeti Foglalkozási Ügynökség (Agence nationale pour l'emploi - ANPE) helyi egységeivel.

47 Lásd erről bővebben BALÁzs István: A francia helyi önkormányzati rendszer átalakulása napjainkban. Államés Jogtudomány, 2016/2, 16-39.

48 A korábbi 22 régióból a regionális önkormányzati választásokat követően 13 nagyrégiót alakítottak ki.

49 Mille feuille territoriale, azaz a „területi leveles tészta” vagy az „ezer falevél”. 
mokkal nem könnyü lebontani. Nem véletlen, hogy Francois Holland is kijelentette, ${ }^{50}$ hogy a megye a francia területi igazgatás integráns eleme marad. A törvényhozás is inkább pénzügyi ösztönzőkkel próbálja elősegíteni a területi szervek, így elsősorban a megye fúzióját más kollektivitásokkal.

\begin{abstract}
The principle of decentralization is widely applied in public administration. Despite the conceptual insecurity decentralization is often linked to the principles of democracy, participation, efficiency providing a normative value for the principle. Practical experiences, however, show that the advantages and disadvantages of decentralization are influenced by historical, economical, social, institutional and cultural context.

Decentralization policy to increase the effectiveness of French welfare services could not change the institutional structure with strong historical roots and to improve the service quality. The strengthening of task and competences of the county level led to the failure of decentralization due to the lack of funding, personal and coordination problems.
\end{abstract}

50 NunÉs, Eric: La décentralisation, nouveau chantier de Hollande? Le Monde, 14.01.2014. 